Jurnal Pengabdian Masyarakat

vol.1 no.1 Oktober 2017

\title{
PEMBERANTASAN BUTA AKSARA AL-QURAN ANAK JALANAN DI SIMPANG PASAR PAGI PEKANBARU
}

\author{
M. Zainuddin, Amir Syamsuadi, Mhd. Rafi Yahya \\ Prodi Ilmu Pemerintahan Universitas Abdurrab \\ zainuddin@univrab.ac.id
}

\begin{abstract}
Take care of street children has been carried out by the Goverment of Pekanbaru, but the results of research on policies to manage of street children still leaves the problems included of illiteracy (especially the Alquran). Finally the program launched by the Goverment of Pekanbaru about maghrib recite of Alquran the period 2012-2017 will not be enjoyed by the street children. Community service activities is done by holding a persuasive approach, which provides guidance and teaching of the Alquran alphabets that are basic characters. The subject are street children in the Simpang Pasar Pagi Pekanbaru within two months. The methods used is to provide intensive managing from the scientific basis of reading and writing the Alquran. The results are the basic abilities possessed by street children in the science of religion. As a result, theranquillity and peace of the community will be created.
\end{abstract}

Key word: street children, manage, reading-writing, Alquran

\begin{abstract}
ABSTRAK
Pembinaan anak jalanan sudah dilakukan oleh Pemerintah Kota Pekanbaru, tetapi dari hasil penelitian tentang kebijakan penanganan anak jalanan tersebut masih menyisakan banyak persoalan salah satunya adalah buta aksara (terutama Alquran). Akibatnya program yang dicanangkan oleh Pemerintah Kota Pekanbaru periode 2012-2017 tentang maghrib mengaji tidak akan bisa disentuh oleh anak jalanan tersebut. Kegiatan pengabdian pada masyarakat ini dilakukan dengan mengadakan pendekatan persuasif, yakni memberikan bimbingan dan pengajaran aksara Alquran yang sifatnya mendasar. Subjek pembinaannya adalah anak jalanan yang berada di Simpang Pasar Pagi Kota Pekanbaru dalam waktu 2 bulan. Metode yang digunakan adalah memberikan pembinaan secara intensif dari sisi keilmuan dasar baca tulis Alquran. Hasil pengabdian ini adalah adanya kemampuan dasar yang dimiliki oleh anak jalanan dalam ilmu agama. Akibatnya, ketenangan dan ketentraman masyarakat akan tercipta.
\end{abstract}

Kata kunci: anak jalanan, pembinaan, baca-tulis, Alquran 


\section{PENDAHULUAN}

Pemerintah Kota Pekanbaru telah mencanangkan program maghrib mengaji. Program tersebut tidak semua lapisan masyarakat dapat melaksanakan program tersebut. Terutama bagi masyarakat yang kurang mampu seperti anak jalanan dan pengamen. Sebagaimana hasil penelitian Zainuddin yang menyebutkan bahwa kebijakan pemerintah untuk memberantas anak jalanan tidak membuah hasil yang maksimal. Akibatnya, anak jalanan tersebut masih tetap ada di Pekanbaru hingga saat ini.[1]

Aspek penilaian penting dari kebijakan Pemerintah Kota Pekanbaru dalam menerapkan maghrib mengaji adalah tidak tersentuhnya seluruh generasi terhadap program tersebut. Telaah tentang pentingnya kesetaraan antargenerasi yang termasuk dalam program pemerintah adalah gagasan kesetaraan. Hal ini telah dipahami dalam pengertian kelas, ras, umur, kecacatan, lokasi dan sebagainya. Menurut perspektif ekologis, bahwa kesejahteraan generasi-generasi masa depan perlu diperhitungkan dalam keputusan-keputusan kebijakan. Pemerintah harus mengidentifikasi bukan hanya calon-calon 'pemenang' dan 'pecundang' dalam lingkungan masyarakat yang ada sekarang, tetapi juga apakah generasi masa depan akan 'menang' atau 'kalah' sebagai akibat kebijakan tertentu. Hal ini menekankan bahwa tanggung jawab sosial berlanjut terus hingga ke generasi masa depan, termasuk kelompok-kelompok yang merasa dirugikan. Oleh karena itu, perlu kebijakan untuk kelas bawah supaya tidak memperburuk dirinya sendiri.[2]

Melihat pendekatan hak-hak, maka setiap generasi juga memiliki hak yang sama terhadap kebijakan tertentu dari pemerintah. Pertama, hak-hak dan tanggung jawab berjalan beriringan. Memiliki hak berarti bahwa orang lain memiliki kewajiban terhadap hak tertentu. Kedua, jika seserorang memiliki hak-hak, maka semestinya masyarakat mendorong dan mendukung pelaksanaan hak-hak tersebut.[3]

Keberadaan anak jalanan sesungguhnya bukan saja permasalahan Kota Pekanbaru, tetapi juga kota besar lainnya. Ada dua masalah sosial yang serius yang masih dihadapi Indonesia adalah kemiskinan dan pengangguran [4]. Untuk itu, sebagai akademisi merasa perlu dilakukan pembinaan terhadap anak jalanan juga sebagai upaya membantu Pemerintah Kota Pekanbaru, terutama dalam pembinaan keagamaan dengan pilihan lokasi di Simpang Pasar Pagi Pekanbaru.

Anak jalanan di Simpang Pasar Pagi berjumlah fluktuatif antara 10 hingga 20 orang. Tidak ada yang tamat sekolah dasar. Tidak bisa baca tulis Al-quran dengan baik dan tidak mengerti melaksanakan ibadah utama seperti sholat. Mekanisme mereka dalam mencari penghasilan adalah dengan membersihkan kaca mobil pengguna jalan, menjual koran, meminta-minta tanpa menampilkan skill, menjual asesoris mobil dan terkadang menjual barang-barang yang sifatnya tentatif. Latar belakang anak jalanan ini adalah berasal dari keluarga tidak mampu dan tidak berpendidikan. Kepedulian keluarga terhadap agama juga kurang.

Kegiatan anak jalanan di persimpangan ini kerap menjadi perhatian pemerintah kota karena mengganggu kenyamanan dan ketentraman para pengguna jalan. Oleh karena itu, Pemerintah Kota Pekanbaru mengeluarkan peraturan daerah tentang dilarang memberikan sumbangan kepada para pengamen atau anak jalanan yang berkeliaran di Kota Pekanbaru. Hal ini juga sesuai dengan yang disampaikan oleh anak jalanan bahwa mereka lebih banyak beraktifitas di hari libur. Kalau di hari kerja, khawatir dirazia oleh Satpol PP Pekanbaru. Pemerintah hanya sebatas 
penertiban (razia), pendataan oleh Satuan Polisi Pamong Praja Kota Pekanbaru (Satpol PP) kemudian diserahkan ke Dinas Sosial untuk diberikan pengarahan.[1]

Sesuai hasil observasi dan laporan penelitian terdahulu, permasalahan anak jalanan di Simpang Pasar Pagi adalah:

1. Tingkat ekonomi dan kemauan belajar yang rendah, sehingga mereka tidak bisa melanjutkan pendidikan.

2. Tidak memiliki skill untuk mencari penghasilan.

3. Memiliki mental yang tidak mau menghadapi hari depan yang lebih baik.

4. Ketidakfahaman mengenai agama (terutama baca tulis Al-quran dan pelaksanaan ibadah sholat).

5. Selalu dirazia oleh Satpol PP Pekanbaru.

Berdasarkan permasalahan di atas, maka fokus masalah yang mau diselesaikan dalam kegiatan pengabdian ini adalah pemberantasan buta aksara Alquran bagi anak jalanan di Simpang Pasar Pagi Kota Pekanbaru.

Kegiatan pengabdian masyarakat dalam bentuk pemberantasan buta aksara Alquran ini diselenggarakan dengan tujuan:

1. Membantu Pemerintah Kota Pekanbaru untuk mengimplementasikan program maghrib mengaji.

2. Memberikan pemahaman kepada anak jalanan tentang pentingnya mengaji.

3. Membantu anak jalanan untuk bisa membaca dan menulis Alquran dengan baik.

Adapun manfaat kegiatan pemberantasan buta aksara anak jalanan ini adalah :

1. Pencapaian salah satu program Pemerintah Kota Pekanbaru

2. Ketentraman bagi masyarakat sekitar Simpang Pasar Pagi

3. Anak jalanan dapat menulis dan membaca Alquran dengan baik

4. Terciptanya komunitas yang produktif dan bermanfaat, terutama komunitas anak jalanan yang sudah putus sekolah.

Pelaksanaan pengabdian pada masyakarat ini, yang menjadi khalayak sasaranya adalah anak jalanan yang berada di Simpang Pasar Pagi Pekanbaru. Jumlah anak jalanan di lokasi ini cenderung berubah. Oleh sebab itu, mereka akan dijadikan kelompok kecil atau komunitas yang keanggotaannya bersifat permanen. Jumlah anggota kelompok yang dijadikan objek pengabdian adalah 5 orang. Mereka adalah anak yang putus sekolah dan tidak bisa baca tulis Alquran. Satu kelompok ini, maka diharapkan akan terciptanya kelompok-kelompok lainnya yang memiliki kegiatan positif.

\section{BAHAN DAN METODE}

Kegiatan latihan baca tulis Al-quran dan dilakukan selama 8 minggu (Oktober dan November) dengan durasi waktu 1 jam/hari, dilaksanakan selama 1 kali dalam seminggu. Kegiatan ini dilakukan pada sore hari. Mengingat, sambil mengisi waktu istirahat kelompok anak jalanan. Objek pengabdian ini berjumlah 5 orang anak jalanan dengan usia tingkat sekolah dasar.

Pemandu latihan ini adalah ketua tim pengabdian yang dibantu oleh 2 orang anggota tim. Berdasarkan hasil diskusi dengan anak jalanan, mereka semua tidak pernah belajar mengaji. Jadi, tim harus mengajarnya dari dasar pngetahuan tentang huruf Alquran.

Pelatihan ini tetap dilakukan di lokasi dekat aktivitas mereka mengamen. Mengingat, hal ini sifatnya positif dan tentu akan mengundang perhatian warga sekitar dan pengguna jalan yang 
lewat. Harapannya, akan ada relawan lainnya yang mau bergabung dalam kelompok tersebut dan anggota kelompok tersebut juga bisa bertambah yang mungkin tidak hanya dari anak jalanan. Disela-sela kegiatan pemberantasan buta aksara tersebut, tim juga mencari relawan yang bersedia membantu memfasilitasi pendidikan anak jalanan pasca kegiatan pengabdian ini dilaksanakan.

\section{HASILDANPEMBAHASAN}

\section{Argumentasi Ilmiah}

Sebelum mengkaji argumentasi ilmiah tentang pentingnya keadilan pendidikan bagi seluruh manusia, terlebih dahulu diungkapkan regulasi yang menjadi landasan kegiatan ini. UndangUndang Dasar 1945 sebagai induk atau hulu hukum di Indonesia, dan khusus berkaitan dengan pendidikan termuat dalam Pasal 28, menegaskan bahwa "setiap anak berhak atas kelangsungan hidup, tumbuh dan berkembang serta berhak atas perlindungan dari kekerasan dan diskriminasi", kemudian "setiap orang berhak mengembangkan diri melalui pemenuhan kebutuhan dasarnya, berhak mendapatkan pendidikan dan memperoleh manfaat dari ilmu pengetahuan dan teknologi, seni dan budaya, demi meningkatkan kualitas hidupnya dan demi kesejahteraan umat manusia".

Anak jalanan merupakan komunitas yang termarjinalkan. Keberadaannya menjadi dilema bagi pemerintah. Pemberantasan anak jalanan dapat dinilai dari dua sisi, pertama, bernilai positif karena pemerintah dapat membersihkan kota dari praktik pengamen dan terlihatnya kemiskinan warga di setiap sudut kota. Kedua, dinilai negatif, karena pemerintah dapat dianggap tidak adil. Sebab pemerintah menutup salah satu bentuk mata pencaharian warganya. Terlepas dari bentuk diperbolehkan atau tidaknya.

Analisis tentang keadilan sosial memberikan wawasan tentang apa yang diperlukan untuk menyelesaikan permasalahan struktur opresif dan bekerja untuk memberdayakan mereka yang termarginalisasi. Ada beberapa prinsip untuk mengkritik keadaan yang selama ini sudah diterima, dan untuk mencari inspirasi bagi alternatif-alternatif yang dibayangkan. Ciri normatif dari kota yang tidak opreasif yang dapat berperan untuk membangun etika hubungan sosial dalam dunia kontemporer. Ciri-ciri ini memberikan beberapa panduan tentang cara-cara partisipasi yang membebaskan dapat didukung.

1. Perbedaan sosial tanpa eksklusi, mereka yang berbeda dapat datang berkumpul, berbagi dan saling memperkaya.

2. Keragaman, struktur mendukung keanekaragaman dan hubungan-hubungan antar kelompok yang berbeda.

3. Erotisisme, perbedaan menggembirakan dan menjadi daya tarik, ketimbangkan menciptakan ketakutan dan ketidakpercayaan.

4. Publisitas, perbedaan dapat terjadi dalam masyarakat, dan semua orang dapat berinteraksi dengan orang yang berbeda untuk mendengarkan dengan baik dan belajar.[2]

Pengertian hubungan sosial yang adil secara sosial, tidak mementingkan diri sendiri dan eksklusif, tetapi emansipatif dan bersifat mendukung pendekatan pengembangan masyarakat. Hubungan yang adil secara sosial bersumber dari perbedaan-perbedaan, tetapi harus didukung oleh lembaga-lembaga sosial yang ada.

Permasalahan sosial merupakan gejala abnormal yang mengakibatkan berbagai unsur masyarakat tidak berfungsi sebagaimana mestinya, sehingga memunculkan serangkaian dampak: kebodohan, ketertinggalan, keterbelakangan, penderitaan, kemarginalan, dan kemiskinan. 
Dampak permasalahan sosial dalam selang waktu yang tidak lama berpotensi menimbulkan persoalan lanjutan yang berkenaan dengan degradasi kualitas sumber daya manusia terutama pengembangan kepribadian, karakter dan moral.[5]

Kaum minoritas yang dalam hal ini merupakan kelompok anak jalanan merupakan kelompok yang harus mendapat perhatian serius dari berbagai pihak. Dalam konteks perubahan sosial, mereka menjadi objek kajian dan objek pengabdian bagi sekelompok yang lainnya. Ada pandangan atau sekelompok yang mempunyai rasa membangun dimana selalu menginginkan adanya kemajuan-kemajuan sesuai dengan tuntutan zaman. Namun, ada pula yang optimis dan berkeyakinan bahwa di kemudian hari ada kehidupan yang lebih cerah, sehingga hati-hati untuk membawa arus perubahan masyarakat. Pandangan lain juga tetap ada yang seolah-olah tidak peduli dengan keadaan lingkungan sekitarnya.[6]

Suatu aspek yang paling penting ditonjolkan dalam melakukan perubahan adalah dimulai dari nilai. Nilai ini bisa berupa keagamaan atau budaya. Apabila nilai dasar telah berubah, maka akan menjadi perubahan pada jati diri, martabat dan integritas seseorang.[7] Dengan demikian, adalah logis apabila aspek nilai sangat lamban berubah, bahkan dapat memakan waktu bergenerasi-generasi baru bisa berubah. Tetapi, sekali perubahan terjadi pada aspek nilai ini, berarti terjadi pula perubahan yang mencakup pada sistem dan kelembagaan masyarakat. Hal ini juga terkandung dalam teori modernisasi, bahwa hal yang paling penting dalam masyarakat modern adalah nilai dan sikap hidup.[8]

Ada beberapa konsep secara umum dalam hal penangan kasus anak jalanan, yakni melakukan tindakan preventif, represif dan rehabilitatif terhadap anak jalanan dan/atau dalam rangka memanusiakan kembali anak jalanan dan / atau pengemis.[1] Keberadaan anak jalanan di sebuah kota merupakan salah satu tantangan dalam mewujudkan cita-cita pemerintah kota khususnya dan masyarakat umumnya untuk mewujudkan tingkat kesejahteraan penduduk kota yang indah, tertib dan aman. Urbanisator yang datang dari daerah-daerah atau dari desa-desa untuk mencari penghasilan dengan keterampilan dan atau keterampilannya tidak sesuai dengan kebutuhan ketenagakerjaan di daerah kota membuat mereka tidak memperoleh apa yang diharapkan. Ada pula sebagian urbanisator atau pendatang yang dengan sengaja datang dari daerah lain untuk mengadu nasib menjadi pengemis sebagai mata pencaharian dan hidup menggelandangan. Dengan demikian, keberadaan anak jalanan tersebut perlu ditangani secara konsepsional dan terprogram agar tidak terjadi kondisi yang lebih rawan yang dapat mengganggu stabilitas keamanan dan ketertiban lingkungan.

Perlu melakukan perubahan terencana sebagai perubahan yang disengaja dengan adanya orang luar atau sebagai anggota sistem yang bertindak sebagai agen pembaharuan yang secara intensif berusaha memperkenalkan ide-ide baru untuk mencapai tujuan yang ditentukan oleh lembaga dari luar tersebut. Jadi, inovasi dan kebutuhan memang harus dibantu untuk berubah dari luar sistem. Jika objek perubahan sosial sudah lebih pandai mendiagnosa perubahan mereka sendiri, maka perubahan tentu akan lebih cepat dan efisien.[6] Dalam hal ini, mungkin agen pembaharu akan bekerja di luar tugasnya atau dalam peranan yang berbeda.

\section{Pandangan Awal}

Data awal tentang kemampuan memahami baca tulis Al-quran anak jalanan Simpang Pasar Pagi Pekanbaru menunjukkan bahwa tidak satu orang pun yang mengenal huruf Alquran (Iqra' 
I). Data ini didapat pada survey awal untuk memilih anak yang memiliki kemampuan rendah dalam memahami baca tulis Al-quran. Dari 20 orang anak jalanan, maka dapat diseleksi dan memungkinkan untuk diajarkan adalah 5 orang. Faktor penyebab tidak semuanya menjadi objek pembinaan adalah karena keterbatasan personil dan waktu tim pengabdian. Kegiatan ini juga merupakan langkah awal untuk mengundang relawan yang lainnya. Jika dilihat dari usia mereka yang rata-rata 6-9 tahun. Semestinya sudah memiliki kemampuan dasar membaca dan menulis Al-quran. Akan tetapi, berbeda dengan kelima anak jalanan tersebut.

Rendahnya kemampuan mereka lebih disebabkan tidak mendapat perhatian dari orang tua tentang keberadaan pendidikannya. Keseharian mereka yang semestinya pada pagi dan sore hari berada di bangku sekolah, dan pada malam harinya mereka berada di masjid atau di rumah untuk belajar mengaji atau baca tulis Al-quran, namun hal itu tidak terjadi. Mereka hidup seharian di jalanan dan bertempat tinggal di pinggir jalan dengan menempati warung-warung yang untuk sementara waktu tidak digunakan olh pemiliknya. Aktivitas mengamen di jalanan mereka lakukan dari siang hingga malam hari.

Selama proses pembinaan anak jalanan yang dilakukan oleh tim pengabdian, intensitas kehadiran mereka jarang mencapai $100 \%$ dari 5 orang tersebut. Hal ini lebih disebabkan karena tingkat antusias mereka juga sangat kurang. Orientasi hidupnya adalah untuk mencari penghidupan. Sudah sejak awal doktrin bagi mereka tinggal di jalanan adalah hanya semata untuk menghasilkan uang untuk memenuhi kebutuhan (makanan) sehari-hari.

Memang, ada satu kelompok mahasiswa yang peduli terhadap pendidikan mereka. Pada tiap sore jumat dan sabtu, mereka mendapat pendidikan atau pelajaran membaca dari sekelompok mahasiswa tersebut, tetapi bukan tentang baca tulis Alquran.

\section{Hasil Pembinaan}

Proses pembinaan baca tulis Al-quran bagi anak jalanan dilakukan dengan pendekatan yang disebutkan oleh Suharto [4], yakni street-centered intervention yaitu penanganan yang dipusatkan dijalan dimana anak jalanan biasa beroperasi, serta community-centered intervention yaitu penanganan yang dipusatkan di sebuah komunitas. Dua pendekatan tersebut merupakan bagian dari empat pendekatan yang dirumuskan oleh Suharto. Satu diantaranya sudah dilakukan oleh Pemerintah Kota Pekanbaru dalam bentuk penanganan kasus umum, yakni institutionalcentered intervention (penanganan yang dipusatkan dilembaga (panti) atau rumah singgah.Dan satu lagi belum pernah dilakukan, yakni family-centered intervention yaitu penanganan yang difokuskan pada pemberian bantuan sosial atau pemberdayaan keluarga.

Sebelum melakukan program mengajar mengaji bagi anak jalanan, tim pengabdian terlebih dahulu melakukan pembinaan mental dan pemberian motivasi. Hal ini dilakukan untuk memastikan bahwa mereka mau serius belajar dan ada usaha untuk berhenti mengamen atau tidak lagi menetap di jalanan, tetapi akan lebih fokus belajar demi masa depan yang lebih baik. Hasilnya, walaupun mereka tidak semuanya bisa hadir pada saat proses belajar baca tulis AlQuran (terkadang hadir rata-rata 4 orang saja), namun materi pelajaran dapat diikuti secara seirama.

Setelah pemberian motivasi, tim pengabdian memberikan sumbangan buku Iqra' sebagai sarana untuk belajar baca tulis Al-quran. Buku Iqra' tersebut dibagikan kepada semua peserta binaan. Rencana awal mendirikan rumah singgah non permanen, akhirnya dibatalkan karena 
biaya yang tidak mencukupi. Tempat proses belajar mengajar dilakukan secara nomaden di sekitar kawasan Pasar Pagi yang memungkin untuk digunakan, seperti di depan teras rumah toko, bekas tempat berjualan yang terpakai lagi, dan di depan warung makan yang ada di kawasan Pasar Pagi.

Tim pengabdian memberikan pemahaman baca tulis Al-quran dengan menggunakan metode klasik, yakni mengajar setiap individu secara bergantian untuk mengenal huruf-huruf dan cara membaca Al-quran yang benar. Terkadang, proses belajar tersebut diselingi dengan metode Ustmani dan bernyayi. Mengingat usia mereka masih anak-anak, maka sudah barang tentu butuh bermain. Untuk itu, metodenya adalah bermain sambil belajar dan diselingi dengan mencicipi makanan ringan.

Proses belajar mengajar ini dilakukan setiap hari jumat sore atau kadang diganti dengan sabtu sore pada setiap pekannya. Waktu yang digunakan selama satu jam tiap pertemuan. Sebelum proses belajar dimulai, terkadang anak-anak diajarkan terlebih dahulu berwudhu, supaya mereka terbiasa untuk membaca Al-quran dan berwudhu terlebih dahulu.
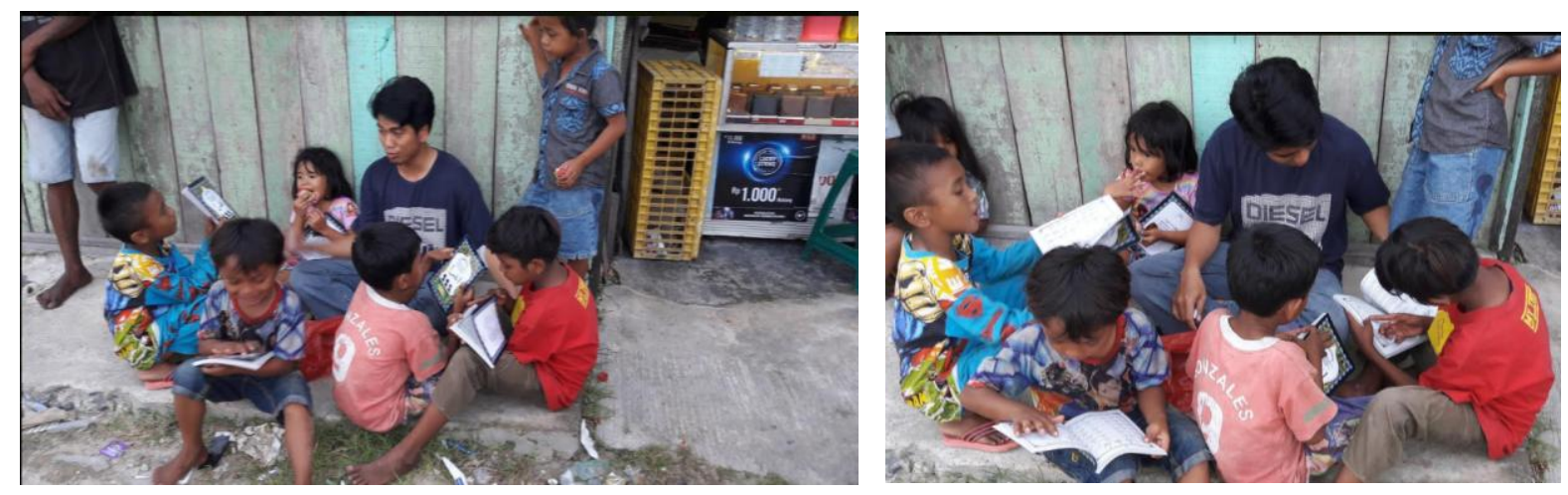

\section{Indikator Keberhasilan}

Memang, intensitas pertemuan yang dilakukan selama 1 jam tiap pekannya tidaklah mendapatkan hasil yang maksimal. Tetapi, karena upaya ini dilakukan adalah sebagai tahap awal untuk membangun kelompok mengaji yang permanen. Berdasarkan kemampuan penilaian awal, mereka tidak mengenal huruf Alquran sama sekali, maka setelah dilakukan pembinaan, mereka sekarang sudah masuk pada level Iqra' II. Selain membaca, para peserta juga sudah mampu sedikit menulis semua huruf-huruf Al-quran.

Selain indikator di atas, pengabdian ini juga akan dianggap berhasil jika keberlanjutan kegiatan belajar ini terus dilakukan walaupun agenda pengabdian ini telah selesai. Menjelang penutupan agenda pengabdian ini, tim telah menemukan relawan untuk meneruskan mengajar mengaji bagi anak jalanan yang ada di Simpang Pasar Pagi Pekanbaru. Relawan tersebut adalah sesosok orang tua yang berjualan makanan ringan yang ada di kawasan Pasar Pagi Pekanbaru dan sekelompok mahasiswa yang peduli terhadap pendidikan mereka yang datang mengajar pada tiap sore jumat dan sabtu. Kemauan ibu dan sekelompok mahasiswa tersebut sangat mempermudah anak-anak untuk belajar. Selain tempatnya yang representatif digunakan sebagai tempat belajar, warung ibu tersebut juga sering tempat berkumpulnya anak jalanan yang lain untuk membeli jajanan. 
Harapan dalam proposal awal dari pengabdian ini adalah munculnya kelompok belajar yang lain dan bertambahnya relawan yang mau membina anak jalanan. Pembinaan tersebut tentunya tidak hanya fokus pada baca tulis Al-quran, melainkan juga pada mental dan pembangunan ekonomi mereka. Adalah hal yang sangat diharapkan jika kehadiran anak jalanan di warung ibu yang melanjutkan proses pembelajaran tersebut maka akan muncul kelompok mengaji yang baru. Meskipun demikian dan sudah selesai program pengabdian, maka tim akan terus memantau perkembangan kelompok mengaji dan berusaha untuk memberikan bantuan baik dalam bentuk sarana maupun pemikiran.

\section{KESIMPULAN}

Memang, anak jalanan merupakan kelompok termarjinalkan. Sudah pasti pendidikan mereka terabaikan. Usaha Pemerintah Kota Pekanbaru untuk menjalankan program maghrib mengaji memang dipandang berhasil, tetapi tidak bagi kaum marjinal seperti anak jalanan. Anak jalanan perlu pertolongan dari pihak non pemerintah atau relawan. Mereka siap mengejar ketertinggalan dari anak-anak yang beruntung lainnya. Program pengabdian ini akan dianggap berhasil jika pendidikan informal anak jalanan tersebut terus berjalan dan berakhir pada titik ketiadaan anak jalanan lagi. Bagi pemerintah, diharapkan tidak menjadikan anak jalanan sebagai musuh, sehingga mereka dipaksa ke rumah pembinaan (panti), melainkan lakukanlah pembinaan tersebut tanpa harus menganggap mereka sebagai kaum terbelakang. Adakan pendekatan secara persuasive dengan mengikuti irama mereka sambil berkombinasi dengan irama kita.

\section{DAFTARPUSTAKA}

[1] Zainuddin M. 2015. Involusi Penyakit Masyarakat (Kajian Penanggulangan Gelandangan dan Pengemis di Pekanbaru). Jurnal Alboacen.Vol.III. Nomor 2: 55-70.

[2] Ife J, Tesoriero F. 2008. Community Development: Alternatif Pengembangan Masyarakat di Era Globalisasi. Yogyakarta. Pustaka Pelajar.

[3] Ife J. 2004. Linking Community Development and Human Rights, Community Development, Human Rights and the Grassroots Conference. Melbourne. Deakin University.

[4] Suharto E. 2008. Kebijakan Sosial Sebagai Kebijakan Publik. Bandung. Alfabeta.

[5] Dumasari. 2014. Dinamika Pengembangan Masyarakat Partisipatif. Yogyakarta. Pustaka Pelajar.

[6] Ranjabar J. 2015. Perubahan Sosial: Teori-Teori dan Proses Perubahan Sosial serta teori Pembagunan. Bandung. Alfabeta.

[7] Kasnawai MT, Asang S. 2014. Perubahan Sosial dan Pembagunan. Banten. Universitas Terbuka.

[8] Salim, A. 2002. Perubahan Sosial; Sketsa Teori dan Refleksi Metodologi Kasus Indonesia. Yogyakarta. Tiara Wacana. 